\title{
Causes and Implications of Prostitution among Young Girls in Maiduguri, Borno State, Nigeria
}

\author{
${ }^{1}$ Bintu Kachalla Galadima \\ Department of Sociology and Anthropology, University of \\ Maiduguri \\ ${ }^{3}$ Ahmed Garba \\ Department of General Studies, Taraba State College of \\ Agriculture, Jalingo
}

\begin{abstract}
This paper focus on causes and implications of prostitution among women in Maiduguri, Borno State, Nigeria. The objectives of this paper was to understand the principal causes influencing the women to enter into prostitution as a business profession for earning money, identify the problems associated with prostitution, as well as challenges the prostitutes encountering while practicing their business of sex services for money. The researchers also suggests some recommendation as the panacea. Prostitution amongst under-aged girls has become an alarming phenomena in Maiduguri, Borno State; led the State Government to demolish most of the brothers, hotels and related alcohol drinking point. The law has granted State Government a vet to ban prostitution and revolve the brothels and hotels who were not legally owned the hotels, hence the intelligent report showed that most of the places demolished has been a criminal meeting point, while abusing underaged girls who are mainly coming from various internally displaced persons camp within the Maiduguri Metropolitan. A descriptive and cohort survey designed method was applied, using participant and non-participant observation with aid of interview. The researchers selected ten (10) different brothels and hotels with random sampling techniques. A sample size of (90) prostitutes were used (9) from each of the ten (1) areas selected. A simple frequency distribution and percentages with the aid of Chi-square was used to distinguish respondents' opinion on the factors attracting them to embrace the sex for money business and it implication. Opinion generated from the respondents and other empirical literatures consulted has simultaneously proved that poverty, hunger, peer group and broken home are the principal causes influenced them to join prostitution.
\end{abstract}

Keyword:- Causes, Implication, Prostitution; young girls.

\section{INTRODUCTION}

Prostitution is a practice of providing sexual services to another person in return for payment. Prostitution is commonly described as a custom of having sexual relations in exchange for economic gain (Qayyum et al., 2013; Wood, 2001). The person who receives payment for sexual services is called a prostitute or sex worker. Prostitution is sometime referred to as "the world oldest profession"

\author{
${ }^{2}$ Baba Gana Alimi \\ Department of Social Services, Ramat Polytechnic, \\ Maiduguri \\ ${ }^{4}$ Hassan Suleiman \\ Department of Social Services, Ramat Polytechnic, \\ Maiduguri
}

(Wikipedia, 2020). Prostitution is a deviant behaviour, a manifestation of a State of lawlessness in which society fails to provide an avenue for individuals to achieve the goals set by the institutions of the society. Clinard (1968: 371-387) further argues that prostitutes have a separate subculture with norms and values that are directly opposed to that of the larger society to the extent that they often run afoul of the laws of the society. The prostitutes sub-culture of the law of the society. The prostitutes are most often associated with stigma, embarrassment, intense occupational involvement and difficulties in leaving the profession. It tries with criminal underworld leave the prostitute open to harassment not only from security agent but from other prostitutes and other members of the criminal population (Kangiwa, 2015: 76).

Prostitution has been a major issues for government, parent and human rights activist, as young girls of 13-16 years old are being smuggled out from their homes to another destination without the consent of their guardians, nor the community (HRA, 1997). In the recent time, prostitution has become a lucrative profession among the young girls between aged of 13-16 years old (Ikpe, 2008). Another study vindicates that most of the prostitutes found in Nigeria are students of various tertiary institutions, who are either currently pursuing their education or graduates without a job or not married. It is obvious that there are different forms prostitutes that stay in brothels, those that stand on the road side, and other who are operating at home (Onah, 2000). However, prostitutions as a business of profit making is evident from the work of (Aday, 1990; Omotolani, 2020) which state that there are ten countries where prostitutions is legal. These countries are Finland, Costa Rica, New Zealand, Austraia, Bangladesh, Denmark, Canada, Germany, Greece, Columbia, Thailand among others. Prostitutions in these countries serves as one of the alternative source of revenue for government, hence, taxes are paid to the government. Ironically, prostitution is an illegal business in Nigeria. A premium times of Sunday, March 29, 2020 has reported that 104 women believed to be prostitutes was arrested in different night clubs in Abuja. According to premium times reporter, Adebowale (2019) out of the 104 prostitutes arrested by police, and taken to court, 27 of them were convicted and sentence to one month imprisonment while some others released and few among awaiting verdict in custody. It is therefore glaring that prostitution is prohibited in Nigeria, under sections 
223, sub-section 224 and 225 of the Nigeria Criminal Code, while Islamic Panel Code is also prohibited the commercial sex work alias prostitutions (Adebowale, 2019). A similar case was reported to have happened in Borno State which led to demolishing of 20 hotels and marked 47 others which believed to have operating as brothels, gangs hidden point and alcohol joints and commercial sex service core, which the Executive Governor of Borno State in person of Gov. Baba Gana Umara Zulum had instructed the Attorney General and Commissioner for Justice to demolish all, hence their certificate of land occupancy condition contradicted the current operation of the land. The Governor has the vets of withdrawing the certificate of occupancy of all places operating illegal and immoral business and activities that undermining the interest of general public. The commissioner for justice, Barrister Kaka Shehu Lawan further said that the decision and action of the Borno State Government was done in response to the intelligence information that such outfits have become security threat as many young girls of 13-16 years old were being drugged and sexually abused by irresponsible adults (Haruna, 2019).

Inspite the existing of law prohibited the prostitution within the context of Nigeria addition with various state government actions against prostitutions practice among under aged girls in Maiduguri, Borno State and Nigeria at large. Unfortunately the prostitution as a business profession among teenagers of between 13-16 years old has continued to gain ground and waxing stronger day after day. Beside, health implication, the proliferation of commercial sex services phenomena has become a major concern for general public, parents, human rights activities, government, religious, community leaders and other concern stakeholders.

It is however obvious that prostitutions of either form has been the vehicles of contracting and spreading or transmission of HIV/AIDs and other related diseases like Sexually Transmitted Disease, yet the business continue to attracts young girls without regards to it negative effects associated with sex services profession. In Borno State, the underaged prostitutions are too alarming that something need to be dome to curb the phenomena of commercial sex service, or prostitution. Although the Borno State Government under the leadership of both successor and predecessor, former Governor, Senator Kashim Shettima and the incumbent Governor Baba Gana Umara Zulum, has demonstrated efforts of demolishing almost most of the places where the prostitutes rendering service, such as Galadima brothels, and other related areas practising the immortality. A task force chairman for demolishing of brothels and alcohol joint points who is also the Borno State Commissioner for Justice, Barrister Kaka Shehu Lawan said as reported by Haruna (2019) that vulnerable underaged girls from various Internally Displaced Persons (IDPs) residing in Maiduguri and Jere Local Government are coming to these brothels demolished to offer sex service for token of amount (Premiumtimes, 2019). It is against this background that the researchers want to find out or investigate the principal factors motivating the underaged girls to engage in prostitutions as business profession, as well as the negative effect of the prostitutions amongst the prostitutes. Finding the causes and the effects of commercial sex services are the objectives of the researchers so as to draw conclusion and recommendation for possible curbing of the menace in Nigeria.

$>$ Objectives of the Study:

- To examine the factors influencing the underaged girls to engaged in prostitutions as a business profession.

- To identify the negatives and positives effects of the prostitution profession.

- To identify the challenges confronting the prostitutes while in their business.

- To recommend the best way forward to overcome the challenges of prostitutions to the barest minimum in Maiduguri, Borno State, and Nigeria at large.

\section{$>$ Hypothesis of the Study:}

- That poverty, hunger, peer group, broken home, money, victim of rapes \& kidnapping competition among others are the principal causes influencing the younger girls to join prostitution as a profession.

- That prostitution has negatives and positive effect on the prostitutes.

- That prostitution involves serious risks and the prostitutes experiencing life threatening from the customers.

$>$ Research Questions:

- What are the specific factors attracted you to join prostitution as a business profession?

- Do you have knowledge of the health hazards involved in the prostitution?

- Did you encountered challenges while transacting your prostitution business?

\section{METHODOLOGY}

A descriptive and cohort survey design method was used to collect the information on the factors influencing the young girls to engage in prostitutions, the implications of the business to themselves and the challenges facing while doing the prostitutions. The information was obtained from the underaged prostitutes located in various places within the State Capital, Maiduguri Metropolitan and its environs. The areas selected for this study are; Barka da Zuwa, Baga road; Tashan journey Bulumkutu; Gazargamu Coca-cola junction; Modu Ganari tudun Gangale; Galadima Sallake da railway line; Artillery point; Wulari alcohol joint; Passer-by prostitutes; Home based prostitutes. The researchers selected ten (10) prostitutes from each of the nine (9) prostitutes joint identified making it a samples of (90) ninety respondents. A purposive random sampling technique was employed to select the respondents from the places mentioned. Several relevant empirical studies and literatures on the subject were thoroughly examined and found relevant. The study instrument of information gathering used was participant observation, interactions, or a discussion and non-participant observation with the 
concern respondents in their respective brothels or joints. All the required efforts have been invested to ensuring that the research demonstrated a level of constituency and standard. A statistical technique of simple frequency distribution and percentages coupled with chi-square was applied to sum up the opinions of the respondents. Though, the paper declined to make the mathematical figures in the content of the work. Yet the opinion of the respondents in respect of the subject is sufficiently discussed.

\section{DISCUSSION}

The findings of the paper questions in community with the study objectives advanced were answered by various respondents selected randomly to compliment the efforts of the researchers. The bulk of the respondents were highly supported the study hypothesis that poverty, illiteracy, hunger, peer group, broken home, victim of rape, envy and competition need for cash among other factors as the principal causes influencing them to indulge prostitutions was strongly accepted by all respondents interviewed. The second hypotheses advanced on whether the prostitutes aware of the negative implications involved in the prostitutions or not was partially responded, but strongly accepted that they were facing a lot of challenges from customers who are patronizing them in sex service for cash business. Therefore, the researchers concludes based on the responses of the respondents that all the three study hypothesis raised has been supported, except the conflicting opinions found in respect of poor awareness among the respondents on positive and negative effects of their business profession (Field Survey, 2020). This is inline with the work of Onah, (2000) that poverty and hunger are the twin factors attracting the young ladies of today to engage in prostitution as a means of sourcing cash for survival. He further opined that most of the underaged girls engaged in commercial sex service work due to lack of neither job unemployment, nor entrepreneur skills to invest their talents to earn money. Ewah (2010) argues that most of the young girls engage themselves in the business specifically for the fun of human sexuality and joy, but not for economic gain or frustration as other exaggerating. He added that illiteracy is also another path influencing them into sex work business. Another evidence from Maria (2007) that young women are most often introduce to the commercial sex business by their intimate peers or friends who were already in the prostitution profession.

The findings of the paper reveals that the principal causes of prostitution is lack of upright socialisation at the tender age of childhood, due to parental death which led to neglect and grow without proper socialisation (Kangiwa, 2015). Similarly, Thomas (1980) is of the opinion that women enter prostitution as result of poor childhood upbringing, family broken home, parental negligence and childhood traumas which prone them to deviant behaviour. Another study revealed that under aged prostitutions enter the prostitution business as a result of ecological factor and unfavourable environment (Samir, 1965)
This work hypotheses which state that poverty hunger and related economic issues are the factor influencing the underaged girls to engage in prostitution profession is strongly supported by Clinard (1996) who argues that prostitution is a by product of poor socio-economic status and geographical areas with a view to improve their economic status to better their lives to cater for the needs of their family (Kangiwa, 2015). According to David (1937) prostitution is economic based exchange of relationship two persons, one participating for pleasure and for cash. Davis, further said that the sexual services between the customers and the prostitution has nothing to do with either party personality or respect, but it is about pleasure and reciprocal reward relationship. The response of the customer likewise it does not depend upon the particular identity of the prostitute, but upon the body gratification (Kangiwa, 2015; Field Survey, 2020). In related development, Qayyum et al., (2013) reported that the biggest reason for involvement into prostitution by young girls was poor economic circumstances and conditions. Poverty is the motivating force to fend their lives for the survival of the family. Qayyum et al., further identified, early forceful marriage, tender aged rape ,husband's drug abuse, domestic clashes, premarital deception by a lover, family betrayal, sex for enjoyment, among other factors are the causes influencing involvement of underaged girls into prostitution (Dachen, 2016; Field Survey, 2020). Contrary to other scholars opinion on why young girls engage into prostitution; Heidenson (1968) and Rosenblum (1975) argued that women become prostitutes because they are primarily defined by men as sexual objects; they are not adequately socialized in sexual and non-sexual interaction, and above all they have lower access than men to educational, economic and political resources (Kangiwa, 2015; Field Survey, 2020). The finding of the study based on the opinions of the respondents reveals that there are a lot of challenges the prostitutes encountering from the men in the process of their business. These challenges are wilful refusal to pay after having sex, kidnapping, beaten and call names, physical abuse and violence, contracting HIV/AIDs, unwanted pregnancy and abortion, rape, societal stigmatization, compelled them to drug abuse, spreads them a diseases, ovarian issues among others are most often glaring with prostitutes (Qayyum et al., 2013; Field Survey, 2020).

ISCA (1999) work coincides with the finding of this study that underaged girls were engaged in commercial sexual activities primarily to meet basic life needs such as accommodation, food, family healthcare drugs, clothing, and money with which to purchase goods, and services. Another researcher, Baker (2000) opines that young girls below the aged of 18 years entering prostitution due to poverty, but other reasons were a desire to rich quick, lack of education, family problems, and behavioural abnormality among other thing. Similarly, Dodsworth (2000) has revealed that "push and pull" factors are another path commonly aiding the entry of young girls into prostitution. The "push" factors included physical and sexual abuse, poverty, neglect, family breakdown, bad experiences of the state care system or inadequate after care 
services, homelessness (often as a consequences of running away), school exclusion, unemployment, and lack of financial support, together with consequent low levels of self-esteem and feelings of powerlessness. The "pull" factors (often reciprocal to the "push" factors) included excitement, freedom, independence, access to money, support from others involved in prostitution, a way of seeking affection, and a sense of power and control in contrast with previous abuse experiences (Davidson, 1998). However, Khan et al., (2013) reveals that denial of opportunities, poverty, financial burdens, the desire to survive, lack of adequate knowledge and the desire for more material assets have made girls and married women in Lahore, enter into a web of selling sex. In another study, Shilla (2011) in his findings found that stakeholders were involved in sustaining the prostitution business. According to him, the major causes of prostitution were attributed to prevalence of prostitution to prevailing poverty, availability or easy accessibility of condoms, peer pressure, illiteracy, family breakdown and family neglect (Qayyum et al., 2013). Evidence also emerged that the social, economic and cultural factors combine to effect women's decision to enter sex business. Other auxiliary factors push women to escape from marital life, includes: freedom from violence, humiliation, earn for self-survival and family, earn easy and quick money, illness in family, lack of education, low socio-economic condition, ignorance of the sex business implication, and dependent children push women into sex work (Sagguni et al., 2011). Therefore, it is glaring to admit that the findings of this study is reflected the reality of the sex business phenomena as the study hypotheses advanced has been scholarly supported to make the work reliable and pathway for other researchers to dwell more on the circumstances surrounding the sex for cash among underaged girls in Maiduguri, Borno State, and Nigeria at large.

\section{$>$ Factors Influencing Women to Prostitutions}

There are numerous factors motivating underaged girls or women to enter prostitutions as a business profession of earning money, but the following are some of the factors influencing the women to prostitution in Borno State, Nigeria as a whole, found in the findings of this study and others cited in the work of (Kangiwa, A.A. 2015; pp7476; Qayyum, S. et al., 2013; pp403-408; Onah, 2000; Ewah, 2010; Maria, 2007; Tiemoko, 2002; Akpan, 2000; Dachen, I. 2016).

- Poverty: Because of the disintegration of the family, misery. Hunger as a form of poverty has forced some parents to sell their children for prostitution. Some girls who engage in sex work do so because; they see prostitution as the only means of survival in order to get daily meals. Poverty also led some girls to sell their bodies for money and as a result become a professional sex work (Onah, 2000).

- Personal Life Style: These set of sex workers call it adventure. Most of the commercial sex service workers get into the business profession just to enjoy the sexually pleasure, but not for economic gain as others misperceived (Ewah, 2010).
- Unemployment: Unemployment has been identified as one of the reasons most girls and boys engage in sex work (Onah, 2000). Due to lack of job opportunities for the increasing rate of graduates, students especially girls resort to sex work as a means of livelihood and survival, unemployment has also pushed many young people into sex work and in most cases against their will (Onah, 2000).

- Illiteracy: With the high rate of illiteracy in Nigeria, many parents can neither read nor write. The youths are not left out in this illiteracy problem. This has resulted in their being deceived into believing that in big cities, milk and honey flows, only to be forced into sex work when they get to the city (Ewah, 2010).

- Peer Group Influence: Many young girls succumb to pressure from their peers who they perceived as having made it. The young girls want to make it to and able to flaunt their influence like other already gained ,not knowing or caring how they accumulate it.(Maria ,2007).On the other hand, many young girls become a commercial sex worker through interaction and association with other experienced prostitutes ,clients, bad friends etc(Kangiwa,A G,2015)

- Rape: Many sex workers have been victims of rape and many being sexually assaulted. The sexual assaults suffered by sex workers continue unchecked because of shame and ignorance (Tiemoko, 2002).

- Death: According to Ewah (2010), some sex workers have been victims of ritual killings. Some commercial sex workers have been gunned down in the streets by unknown gun men, while some who are lucky to be alive are left with some bodily harm especially those who have had acid poured on them and those knocked down by vehicles.

- Lost of Esteem: Sex workers lack of confidence. Akpan (2002) had said that, commercial sex workers consider themselves as nobody, since there is lack of confidence; they consider themselves as misfit in the society. He went further said that, the situation has turned them into object or instrument for others to satisfy.

- 9. Sexual experience and feelings; The biological nature of man and sexual desirability are some of the factors leading women venture into prostitution .Sexual desirability as a factor also generating prostitution is not tenable since few women enter into the sex services work to satisfy and indiscriminate sexual appetite .It is also argued that early sexual experience further motivating them to continue servicing sex.(Kangiwa,A G,2015).

- Socio economic Predicaments: The Predicaments of abject poverty,hunger,the effect of living in slums and most populated areas occupied by low income earners, lack of financial muscles to treat illness (Kangiwa,A G,2015).

- Prostitute subculture: This factor stresses that girls become prostitutes through interaction and association with other prostitutes, peer groups, clients, steerers and procurers, in some cases pimps, in others lesbian lovers, police and other security agencies. 
- Family broken: Family broken up of either divorce,illness, death or any other related problems that might consumes one or both of the parents or heads of the family could render the children to lack the basic discipline, guidance and parental love. Children grew up under such predicaments and uncertainty either a male or female felt despaire, thus leading to alternatives path on his/her own to survive.

- Ecological considerations: Ecological factors such as migration and urbanization are often given as reasons contributing to prostitution. Faced by the break down in her life pattern and the failure of the traditional ties to her rural community to sustain her, the urban dweller may easily yield to her urge for sexual promiscuity and a life which promises comfort and ease.

- Effect of Boko Haram Insurgency: The Boko Haram crises has consumed the lives of approximately 38,000 innocent peoples were killed, rendered thousands of women widows and more than thousands of children's to orphans. Besides the Boko Haram also burnt houses and carted away with their food and non food items which mandated the victims to flee from areas of their origin to another destination as internally displaced persons. These deprivation, humiliation, frustration and distress situation led many of the young girls resort to engage into prostitution as a source of getting money to survive with their families (Field Survey, 2020).

- Hardship and debt servicing; Economic hardship and effort to settle borrowed debt are some of the reasons influencing most women involvement into commercial sex service work in most family and society.

- Chronic Illness in the family: Inability of a family to effectively manage or take care of it members who are suffering from a terminal diseases like kidney or liver problems could force the member of the family to out and source for cash so as to rescue his/her life.However,these most often influencing the female members of the family to join prostitution as alternative means of earning income by medication and restore the live of their family member.

- Alcoholic Husband and Family Burden: There are many head of a family who are constantly abusing drugs of all of sort, including alcohol and marijuana, yet leaving jobless without anything to do get income.Unfortunately, they have many children whose survival depend on him. As a result of this pathetic situation, the wife and other women of the family had to resort for means of sourcing income thereby find themselves into prostitution all with a view to survive with their family ,hence the head of the family survival.(Field Survey.2020)

- Sourcing for money to Support family: The desperation of women for material gains to leave in a luxury life is another critical path towards their involvement into prostitutions with a view to satisfy the needs of their family members to compete with others. This situation is glaring in most organization .For example, in an academic environment, the scandal of grade for sex was a good example and women are most often the victim.
- Child marriages and Domestic Violence: Given out a daughter to marriage at the tender aged below the aged of 18 years could likely undermine health of the daughter and lacking autonomy and support as well as veto over their husband and inlaws. Therefore,they are vulnerable to domestic violence and abandonment. The violence including sexual, physical and psychological abuse. Most often the husband of the girl married before the aged of 18 years were being beaten and threaten by husband, than women who were married after 18 years of aged.Inview of these, child marriage and it attendant consequences aiding marriage break up or divorce and thereby engage in prostitution for survival.

- Forced rape: Most of young girls who found themselves in the profession of commercial sex service work were once a victim of forced raped at the tender aged before the aged of 18 years .The agony of the raped experienced, coupled with pleasures involved and poverty are the ingredients for formed to drive the young girls victims to the business of sex service.

> Challenges prostitutes encountering from their customers after having sex:

According to Qayyum, S. (2013; pp405-408), Tiemoko, (2002), Ewah (2010) and Akpan (2002), the following are some of the challenges prostitutes receiving from the men who are patronizing their business.

- Wilful Refusal to pay: Most of the prostitutes expressed their experiences in view of reward and payment after having sex with their customers. Some women reported that initially they entertained their customers as their will and wishes but not paid for their work. They explored these incidents occurred when they were encroached far away from their home places and when didn't have pimps for this profession.

- Kidnapping and sexual assault; It was reported that most of the prostitutes were a victims of kidnapped and sexual assaults. Some of them kidnapped during their sex service business period by a unknown gun men believed to have to have been connived with their former customers .However, the victims are forced to sexually harassed, and asked to do many things against their wishes and consent.

- Inhumanely Treated: Most of the women prostitutes mentioned that they were often beaten and calling abuse by the customers in different time periods. Almost all the women were beaten more and less and some or few times. They raised the issue that we were the entertaining source for men in spite of that they were treated inhumanity often.

- Physically abuse and violence: Physically abuse and violence and related cases were glaring among prostitutions. Some of the prostitutes described their experience in view of violence. Most of them were below the aged of 22 years when were physically and sexually abused by customers. Their clothes had been torn and made them naked, tied very tightly and put taste on their mouth. They rapped them like animals for 3 hours consecutively than Some times they lighted a candle and its burned oil started throwing on their breast 
drop by drop that was very bitter and painful for them. After that they lighted a cigarette and touched it to their body on different parts. Most often were crying but no voice. Besides, burned their legs (thighs), buttocks and nipple of their breast little bit.

- Alcohol and drug abusing: Some of the prostitutes shared their lives' exposure regarding drug abusing customers. The prostitutes described that their husbands were the addicted of drugs that become the reason of separation and being prostitutes. They were treated so badly as if they are slave.

- Children's Burden and Survival: Some women explored that they wanted to leave the profession but remained just for the sake of their children's lives. They were regular sex worker at the age of 25 years. Most of them had either 2,3 or 5 children who were under the control of their pimps. After the death of their husband they don't have a means to survive nor have a house to live.Inview of that we were resorted to join the prostitution as a means of survival.

- Health implications: Women prostitutes explored that they had been survived and sustained numerous times from different diseases .Most of them are not taking measures to protect themselves against the dangers of serving multiple sex costomers, hence conducting the business without using condom nor have access to strong antibiotic in case of ordinary sexually transmitted.

- Unwanted pregnancy and abortion: A few prostitutes explained that initially when they began the sex for cash business, many of them conceived pregnant unknowingly. Almost all of the prostitutes had been pregnant once in their lives except few due to ignorance.

- HIV/Aids: It was found that very few girls were aware of the existing of HIV/AIDS. Most of the prostitutes are either had one venereal disease or had other common sexually transmitted diseases. However, three among were confessed to have contracted with HIV/AIDS in the sex service profession.

- Drug addiction: Most of the prostitutes said that they used to take drugs like smoking, alcohol etc.Many of them were 14 years of age when joined this profession voluntarily. After spending 1 and half years in this profession, became drug addicted. They used to take alcohol and smoking marijuana regularly and all sort of drugs.

- Ovarian issues: Some women prostitutes highlighted ovarian issues that had been experienced by them in prostitution profession. Most of them regularly entertained many people approximately 11 to 13 people in day. They didn't care of their health anymore.

- Common Diseases Prostitutes Contracted : Almost all the prostitutes had one common diseases or the others, like stomach upset, headache, hepatitis, blood pressure, irregular menstruation problems, breathing issues, liver pain and some psychological issues such as, depression, anxiety, frustration, anger, etc.
- Societal Perception: Some of the prostitutes who had been working for entertaining the people as their wishes but they were treated very badly. The prostitutes explored the issue that they were not considered human but animal and only the source of entertaining. Peoples had very negative perceptions towards them without knowing their situations and circumstances surrounding their job status.

\section{Classification of Prostitution and where they work:}

According to Fuchs, (2015). Prostitutes are divided into various forms. These include the followings:

- Inadequate call girls/escort

- Escort agency employee

- Brothel employees

- Window sex worker

- Bar or casino worker

- Street walker

- Sex tourism

- Visual sex

$>$ Positives and Negatives Consequences of Prostitutions According to Clinard, (1968: pp385) as in Kangiwa (2015: pp75-76) and Vella (2019) prostitution perform both positive and negative effects.

- Positive Consequences:

$\checkmark$ Prostitution serves as a sexual outlet for some men and therefore protects the society from more rapes, perversions and broken marriages.

$\checkmark$ Prostitution has achieved certain dominant values in the society such as success and supports others who are dependent on them.

$\checkmark$ The prostitute who enters the life of a call-girl from the lower socio-economic status has experience an upward mobility.

$\checkmark$ Prostitution satisfies the need of some men who are temporarily separated from their normal regular sexual partners and lovers.

$\checkmark$ Prostitutes help provide sexual variety and the opportunity to experience new methods of sexual intercourse.

- Negative Consequences:

$\checkmark$ Prostitution is a necessary evil that constitutes a threat to the moral standards of the society.

$\checkmark$ Prostitution is illegal and is punishable by law. A greater percentage of women serving in jails are prostitutes.

$\checkmark$ Because of the stigma attached to prostitution, prostitutes have very few non-deviant friends in whom to confide.

$\checkmark$ Prostitution results into severe outbreak of venereal diseases as well as in other female criminalities such as theft/stealing, armed robbery, drug trafficking, murder, child abandonment, abortion etc.

$\checkmark$ Prostitutes exploit customers especially if they know that the customer will not report the crime for fear of public exposure. 


\section{CONCLUSION}

Prostitution as a profession exists throughout world. It has been around for centuries and described as the world oldest profession. No known societies whether modern or traditional, exist without some form of prostitution and Nigeria is no exception. In the past few years, many western oriented countries have been debating as whether it should be legalized or not. It is difficult to refute the fact that prostitution has negative effect on the individual engaged it as business profession and the society operating the business at large. It is globally proven that the destructive consequences of commercial sex business are similar whether the profession is legal tolerated or illegal. The child sexual abuse and exploitation are complex phenomena that demand a multi-disciplinary and wellintegrated response (Field Survey, 2020).

The findings of this paper has justified the decision and action of Borno State Government of demolishing some brothels, hotels and other related joints where underaged girls are operating their business as sex service for money (Haruna, 2019). Besides there are many other illegal structures marked by Borno State Government for demolishing for operating illegal activities that undermining the general public interest. According to the Commissioner for Justice, Barrister Kaka Shehu Lawan, the places, if continue to operate, it become a security threat to Borno State and the North East at large (Haruna, 2019). The study findings discovered that most of the underaged women rendering sex services were from various internally Displaced Persons Camps (IDPs) leaving within Maiduguri and its environs. It should be noted that prostitution is prohibited in Nigeria, under sections 223, sub-section 224 and 225 of the Nigeria Criminal Code, while in the Northern part region, Islamic Panel Code granted veto to various States Government to prohibits commercial sex business. Inview of these, the Borno State Governor, Baba Gana Umara Zulum, act to sanitize the worrisome phenomena of prostitution and protect the right of the innocent girls tricked into the sex business as UNICEF, UN and Human Rights Organization demand to protect the children below the aged of 18 years old (Field Survey, 2020). The findings of this paper in conformity of the respondents responses revealed that poverty, hunger, peer group, broken home, need for cash, and envy for comfortable life among other things are the principal factors attracted them into the prostitution or commercial sex service business profession. These has vindicated that economic predicament is motivated them into the commercial sex work, so as to earn money to buy essential needs to survive with their family. It has been observed that few amongst the prostitutes interviewed are secondary schools and diploma holders, yet unfortunately behaving like their illiterate colleagues, operating the business ignorant of the health hazards or implication, nor using essential infections prevention measures. The study also noted that despite the demolishing of most of the brothels and hotels where the prostitutes running their illegal business of sex service for money, unfortunately, the prostitutes continue to operate at the nearby licensed hotels, while others standing beside a street, park or public places and soliciting for a customers or clients. The researchers, however, concludes that the action and decision of the Borno State Government of demolishing the illegal structures where prostitutes and other criminal hiddens have yielded a positive results in area of security and morality in Maiduguri, Borno State. It has been found that the prostitutes are facing challenges from their customers leading to physical assault or violence and injuries. And most often the prostitutes are operating their illegal profession under the influenced of drugs, such as Marijuana and other related hard drugs for a reasons only known to them (Field Survey, 2020).

\section{RECOMMENDATIONS}

Based on the result of this paper following recommendations are made to tackle the commercial sex business phenomena in Maiduguri, Borno State and Nigeria at large.

$>$ That Borno State Government should continue to act on matters affecting the plight of the general public, thereby implement the full scale recommendations of the committee of frustrating the operation of prostitutions in Maiduguri, Borno State, hence the law prohibit the prostitution granted absolute power to State Government to ban the prostitutes from practising their illegal business.

$>$ That the Borno State should as a matter of urgency establish and initiate an entrepreneurship skills development programmes to train the like of these prostitutes in various skills acquisition to become selfreliant and independently generating money to provide the essential needs for themselves, hence the motive behind the prostitution is economic predicaments.

$>$ That there should be sex education syllabus right from primary to secondary level, so as to educate them on the health a hazard involves in indiscriminate sex disorder; hence most of them are ignorant of the implications.

$>$ That there is need to establish a committee of ward level stakeholders on sensitization campaign on HIV/AIDs and other venereal diseases.

$>$ That parent should monitor the movement of the daughters beginning from the tender age to the puberty level, so as to inculcate with them the spirit of morality, discipline and good behaviour that could brighter future and the family as a whole.

$>$ That parent should allow their daughters to choose the husband of their wishes where necessary so as to establish permanent stability in their marital journey.

> That Government, NGO's, INGO's and well to do members of society should as a matter of urgency endeavour to identify the most vulnerable household assists them with cash and kinds, food and non-food items to survive with their family. Besides, there is need to offer them a scholar ship to enrol their schools. 


\section{REFERENCES}

[1]. Aday, P. (1990). Public Administration in Nigeria. London: Longman Press.

[2]. Adebowale, N. (2019). Arrest of Women in Abuja; What Nigerian Law says about Prostitution. www.premiumtimes.ng.com. Sun, March, $29^{\text {th }} 2020$.

[3]. Akpan, C. (2002). History of Prostitution. In Hussaini A, (ed.) Causes, Types and Consequences of Prostitution on Women in Sokoto State, Nigeria: implications for small scale enterprises counselling 2016. Scholar.google.com $16^{\text {th }}$ April, 2020.

[4]. Baker, S. (2000). The changing situation of Child Prostitution in Northern Thailand: A Study of Changwat Chang Rai, ECPAT International, Bangkok.

[5]. Clinard, M.B. (1968). Sociology of Deviant Behaviour (4 ${ }^{\text {th }}$ ed.) New York: Holt Rinehart and Winston.

[6]. Dachen, I. (2016). 10 Reasons ladies go into prostitutions. $\quad$ www.pulse.ng/pulse-list-10-reasonladies-go-into-prostitution. November, 16, 2016/ECE Auto-Gen.

[7]. Davidson, J. (1998). Prostitution Power and Freedom, University of Michigan, Chicago.

[8]. Davis, K. (1937). The Sociology of Prostitutions in American Sociological Review. Vol.2.

[9]. Dodsworth, J. (2000). Child exploitation and child prostitution: How can the views of the young people involved inform multi-agency practice towards a more effective means of working in partnership with them? Social work monographs, University of East Angila, Norwich.

[10]. Ewah, D. (2010). Prostitution in Nigeria: Religion and the Nigeria Nation. Ibadan: Enjoy Press and Books.

[11]. Field Survey (2020). Effects of Prostitution Among Young Girls in Maiduguri, Borno State, Nigeria.

[12]. Fuchs, E. (2015). The 6 types of prostitutes and where they work. $w$ ww. businessinside.com. Retrieved on $12^{\text {th }}$ April, 2020.

[13]. Haruna, A. (2019). Why Borno Government is Demolishing brothels, and Alcohol Joints. Premiumtimes.com $5^{\text {th }}$ October, 2019.

[14]. Heidenson, F. (1968). The Davience of Women: A Critique and an inquiry In, British Journal of Sociology. Vol.19.

[15]. Ikpe, J. (2008). Physical background in South - South Nigeria. Kaduna: Alaam Publishing Press.

[16]. ISCA, (1999). A Review of Literature on Child Prostitution. Social Policy Journal of New Zealand. Te-puna.www.msd.govt.nz. issue, 19; Dec. 2002.

[17]. Kangiwa, A.G. (2015). The socio-economic factors and effects of prostitution in Nigeria. European Journal of Research in Social Science. Vol.3-No.5, 2015. ISSN: 20566-5429.

[18]. Maria, G. (2007). Prostitution as Global Problems. Uyo. Network Ltd.

[19]. Omotolani (2020). 10 countries where prostitution is legal. $\quad$ www.pulse.ng/lifestyle/fd.us-travel.10countries-where-prostitution-is-legal. $2^{\text {nd }}$ May, $2020-$ ECC Auto-Gen.
[20]. Onah, C. (2000). Prostitution in Nigeria: Religious and Nigerian Nation: Ibadan Enjoy Press, Ltd.

[21]. Qayyum, S. et al., (2013). Causes and decision of women's involvement into prostitution and its consequences in Punjab, Pakistan. Academic Research International Journal. Vol.4. No.5, September, 2013. ISSN-22349558-2223-9944. www.researchgate.net/publication, 2329504666.

[22]. Rosenblum, K.E. (1975). Female Deviance and the Female Sex Role: A Preliminary Investigation in British Journal of Sociology. Vol XXXVI No.2.

[23]. Samir, K. (1965). Prostitution in a Changing Society, Lebanon, Khayas Beirut.

[24]. Suggurti, K. et al., (2013). Poverty of opportunity forcing women into prostitution. Healthcare for Women International.

[25]. Thomas, S. (1980). Social problems: Divergent perspectives. USA: John Wiley \& Sons.

[26]. Tiemoko, R. (2002). Evolving transactions in sexualities. Lagos: Derby Press.

[27]. Vella, S. (2019). I work with prostitutes. The negative effect of prostitution. Daily faith experience. Universeoffaith.org.2019.

[28]. Wikipedia (2020). Prostitution is a world oldest profession. en.m.wikipedia.org. under CCBY-5A3.0 Retrieved on $12^{\text {th }}$ of April, 2020.

[29]. Wood, (2001). Making sense of Prostitution. New York: St. Martin's Press, Inc. 